\title{
PREFERENSI KONSUMEN TERHADAP BUAH-BUAHAN LOKAL DAN ORGANIK SERTA IMPLIKASINYA TERHADAP PENDIDIKAN KONSUMEN CINTA PRODUK NASIONAL
}

\author{
Ujang Sumarwan ${ }^{1^{*}}$, Eny Palupi ${ }^{2}$ \\ ${ }^{1}$ Departemen IImu Keluarga dan Konsumen, Fakultas Ekologi Manusia, Institut Pertanian Bogor, Bogor, 16680 \\ Indonesia, \\ ${ }^{2}$ Departemen Gizi Masyarakat, Fakultas Ekologi Manusia, Institut Pertanian Bogor, Bogor 16680, Indonesia.
}

*E-mail: sumarwan@apps.ipb.ac.id

\begin{abstract}
Abstrak
Penelitian ini bertujuan untuk menganalisis faktor-faktor yang memengaruhi preferensi terhadap buah-buahan dan mengukur preferensi konsumen terhadap tiga atribut buah-buahan yaitu jenis buah, asal buah (lokal dan impor), cara budidaya buah (organik dan non-organik), serta menentukan atribut apa yang lebih disukai oleh konsumen. Penelitian ini melibatkan responden sebanyak 391 mahasiswa Institut Pertanian Bogor yang dipilih berdasarkan metode non-probablility sampling yaitu convenience sampling. Survei dilakukan dengan interview langsung menggunakan kuesioner dengan pertanyaan dan pilihan yang terstruktur. Data dianalisis menggunakan metode analisis regresi berganda dan konjoin. Hasil penelitian menunjukkan bahwa responden memiliki preferensi yang paling tinggi terhadap atribut keorganikan/budidaya buah-buahan organik, diikuti oleh aspek asal buah dan jenis buah. Responden lebih menyukai buah organik dibandingkan dengan buah nonorganik, buah lokal lebih diminati dibandingkan dengan buah impor. Hasil penelitian ini memberikan implikasi penting bagi pendidikan konsumen untuk cinta produk buah-buahan nasional. Preferensi konsumen terhadap buah lokal serta organik perlu terus dipertahankan dan ditingkatkan melalui pendidikan konsumen. Pendidikan konsumen ini diperlukan untuk membangun semangat cinta produk buah-buahan nasional serta meningkatkan pengetahuan konsumen tentang manfaat buah-buahan organik.
\end{abstract}

Kata kunci: atribut buah-buahan, buah lokal dan organik, preferensi konsumen

\section{Consumers' Preference towards Local and Organic Fruits and Its Implications for Consumer Education}

\begin{abstract}
The objectives of the study were to analyze factors influencing preferences towards fruits and to measure consumer preference on the three attributes of fruits which is a type of fruit, fruit origin (local and imported), as well as the way of cultivation (organic and non-organic) fruits and determine what attributes are more preferred by consumers. The study involved 391 respondents students of the Bogor Agricultural Institute who were selected by convenience sampling technique. The survey was conducted by direct interview using a questionnaire with structured questions and choices. Data were analyzed using multiple regression and conjoint analyses. The results showed that the respondents have the highest preference to attribute cultivation of organic fruits, followed by aspects of the locality and the type of fruit. Respondents preferred organic fruit as compared to non-organic fruit, local fruit is more desirable than the imported fruit. The results of this study provide important implications for consumer education to love national fruit products. Consumer preferences towards local and organic fruits need to be maintained and enhanced through consumer education. Consumer education is necessary to build a spirit of love national fruit products and to increase consumer knowledge about the benefits of organic fruits.
\end{abstract}

Keywords: consumer preferences, fruit attributes, local and organic fruit

\section{PENDAHULUAN}

Penelitian mengenai preferensi konsumen terhadap buah-buahan sudah banyak dilakukan. Namun, sebagian besar penelitian tersebut berfokus untuk menganalisis preferensi konsumen terhadap satu jenis buah-buahan, misalnya preferensi konsumen terhadap buah durian (Santoso et al., 2008); preferensi terhadap buah jeruk (Savitri et al., 2016; Rajagukguk et al., 2013; Sadeli \& Utami, 2013), preferensi terhadap buah mangga (Hadayanti et al., 2016); preferensi terhadap buah pepaya Calina (Prihatiningtyas et al., 2015); preferensi terhadap buah pepaya (Sutomo et al., 2015), serta preferensi 
terhadap buah apel (Widiyanto et al., 2016). Sementara itu, penelitian Sukmaningtyas dan Hartoyo (2013) mengungkapkan preferensi konsumen terhadap buah apel, jeruk, serta kelengkeng. Penelitian tersebut juga mengukur sikap konsumen terhadap buah-buahan berdasarkan evaluasi atau sikap konsumen terhadap beberapa atribut dari buah-buahan tersebut (jeruk, mangga, durian, papaya, apel) (Rajagukguk et al., 2013; Sadeli \& Utami, 2013; Sungkawa et al., 2015; Widiyanto et al., 2016; Prihatiningtyas et al., 2015; Savitri et al., 2016; Santoso et al., 2008). Sebagian peneliti menyebutkan sikap konsumen tersebut sebagai preferensi terhadap buah-buahan.

Beberapa penelitian membandingkan preferensi antara buah lokal dan impor (Savitri et al., 2016; Sadeli \& Utami, 2013; Widiyanto et al., 2016; Sukmaningtyas \& Hartoyo, 2013). Penelitian Rajagukguk et al. (2013) dan penelitian Sadeli \& Utami (2013) membandingkan sikap konsumen terhadap beberapa atribut buah jeruk untuk jeruk lokal dan jeruk impor. Sementara itu, penelitian Widiyanto et al. (2016) membandingkan sikap konsumen terhadap apel impor dan apel lokal. Penelitian Sukmaningtyas dan Hartoyo (2013) menunjukkan bahwa responden lebih menyukai apel impor dibandingkan apel lokal. Namun responden lebih menyukai jeruk lokal dibandingkan jeruk impor, dan responden lebih menyukai kelengkeng impor dibandingkan kelengkeng lokal. Penelitian lainnya yang dilakukan oleh Sungkawa et al. (2015) berfokus kepada pengukuran preferensi terhadap buah lokal berdasarkan atributnya. Rajagukguk et al. (2013) menunjukkan bahwa responden lebih menyukai jeruk impor. Penelitian yang mirip dengan penelitian Rajagukguk et al. (2013) dilakukan oleh Sadeli dan Utami (2013) yang menunjukkan rata-rata skor untuk semua atribut jeruk impor sedikit lebih besar $(2,9)$ dari jeruk lokal $(2,8)$. Perbedaan sekecil itu menunjukkan bahwa tidak berbeda nyata sikap konsumen terhadap jeruk lokal dan impor.

Pengukuran beberapa atribut buah-buahan juga dilakukan oleh Sungkawa et al. (2015) menunjukkan bahwa sekitar 66,0 persen dari responden menyetujui bahwa ketersediaan buah lokal sebagai faktor penentu terhadap preferensi buah lokal. Penelitian yang sama dilakukan oleh Widiyanto et al. (2016) menunjukkan bahwa konsumen lebih menyukai buah apel impor dibandingkan apel lokal. Tiga penelitian berikut ini juga sama dengan penelitian yang telah dikemukakan sebelumnya yaitu berfokus kepada sikap konsumen terhadap beberapa atribut buahbuahan. Prihatiningtyas et al. (2015) membuat peringkat preferensi terhadap 14 atribut dari buah papaya Calina. Savitri et al. (2016) meneliti preferensi konsumen terhadap buah jeruk. Santoso et al. (2008) meneliti preferensi konsumen terhadap buah durian di 7 provinsi. Responden diminta memilih karakteristik durian yang disukainya.

Berdasarkan kajian penelitian terdahulu dapat disimpulkan bahwa penelitian sebelumnya berfokus kepada pengukuran preferensi satu jenis buah-buahan, membandingkan preferensi buah lokal dan buah impor untuk satu jenis buah-buahan, serta mengukur sikap konsumen terhadap beberapa atribut buahbuahan untuk satu jenis buah. Penelitian ini mengukur preferensi dari tiga atribut buahbuahan, yaitu jenis buah, asal buah, dan jenis budidaya buah. Setiap atribut dari buahbuahan diperlihatkan beberapa taraf atau level. Untuk atribut jenis buah, responden diminta menunjukkan preferensinya terhadap beberapa jenis buah-buahan, yaitu pisang, jeruk, semangka, lainnya. Kategori lainnya untuk menampung preferensi terhadap buah lainnya dan responden diminta menuliskan buah lainnya tersebut. Selanjutnya, atribut asal buah yang memiliki dua taraf, responden diminta menyebutkan preferensinya terhadap buah lokal atau buah asing. Terakhir adalah atribut budidaya yang memiliki dua taraf, responden diminta menyebutkan preferensinya terhadap buah organik atau non-organik. Budidaya buah-buahan organik sangat terkait dengan konsep keberlanjutan (sustainability). Keberlanjutan merupakan isu global yang penting untuk selalu dijadikan bahan pertimbangan dalam setiap sektor kehidupan demi kualitas keberlangsungan hidup selanjutnya (Kohtala, 2014; Ceulemans et al., 2015). Penelitian ini menggunakan metode konjoin untuk menganalisis preferensi konsumen terhadap atribut buah-buahan tersebut.

Teori preferensi yang menggunakan analisis konjoin disebut sebagai a choice-based conjoint analysis (CBC). Teori tersebut mengemukakan bahwa dalam analisis konjoin berdasarkan pilihan, setiap responden harus memilih salah satu pilihan dari sejumlah pilihan pada tingkat yang berbeda atau memberikan peringkat atau preferensinya kepada berbagai pilihan yang disediakan. Responden memilih pilihan yang menawarkan utilitas maksimum (Li \& Hudson, 2016). Selanjutnya Lu et al. (2016) mengemukakan bahwa analisis konjoin berdasarkan pilihan (CBC) sebagai metode 
mengukur preferensi dikembangkan berdasarkan teori utilitas acak (the random utility theory). Berdasarkan kerangka teori utilitas acak, diasumsikan dalam CBC bahwa konsumen memilih sebuah objek dengan karakteristik yang dapat memberikan utilitas maksimum kepada konsumen.

Penelitian ini bertujuan untuk menganalisis faktor-faktor yang memengaruhi preferensi terhadap buah-buahan dan mengukur preferensi konsumen terhadap tiga atribut buah-buahan yaitu jenis buah, asal buah (lokal dan impor), serta cara budidaya buah (organik dan non-organik), serta menentukan atribut apa yang lebih disukai oleh konsumen.

\section{METODE}

Disain penelitian adalah survei. Pengambilan data dilakukan di Institut Pertanian Bogor di Darmaga untuk mahasiswa sarjana dan di Sekolah Bisnis IPB Bogor untuk mahasiswa pascasarjana Program Magister Manajemen. Populasi penelitian ini adalah mahasiswa Institut Pertanian Bogor. Waktu penelitian adalah Maret 2015 dan Juli 2015. Teknik pengambilan contoh adalah secara sengaja (convenience sampling). Contoh mahasiswa sarjana masih sangat relevan dengan topik penelitian ini karena mahasiswa adalah konsumen muda yang juga mengonsumsi beragam buah-buahan. Contoh mahasiswa pascasarjana juga menggambarkan sebagian populasi penduduk yaitu penduduk yang memiliki rentang usia antara 24-50 tahun serta berstatus bekerja. Kelompok penduduk ini juga adalah konsumen potensial untuk buahbuahan nasional.

Variabel utama atau variabel dependen adalah preferensi terhadap jenis buah-buahan yang memiliki karakteristik buah lokal atau impor serta buah organik atau non-organik. Skala pengukuran dari dependen variabel adalah interval. Pengukuran dan penilaian dari variabel dilakukan dengan cara meminta responden untuk memberikan preferensi terhadap tiga atribut dari buah-buahan, antara lain: budidaya, asal buah-buahan, dan jenis buah. Setiap atribut memiliki kategori atau taraf atau level. Responden diminta memberikan penilaian atau tingkat preferensi mereka terhadap buah pisang, jeruk, semangka, atau buah lainnya. Responden diminta memberikan penilaian atau tingkat preferensi mereka terhadap buah-buahan lokal dan buah-buahan asing atau impor. Selanjutnya, responden diminta memberikan penilaian atau tingkat preferensi mereka terhadap buah-buahan yang dibudidayakan dengan cara organik dan non-organik. Berdasarkan atribut dan masing-masing taraf tersebut, dibuatlah sebuah tabel yang mengkombinasikan ketiga atribut dan tarafnya, kemudian responden diminta memberikan skala preferensi dari setiap kombinasi atribut dan taraf dengan skala rating 1 sampai 10 . Skala 1 artinya sangat tidak suka, dan skala 10 artinya sangat suka. Skala rating ini memiliki skala pengukuran interval. Tabel preferensi kombinasi atribut dan taraf yang harus diisi responden adalah sebagai berikut. $\mathrm{Yi}$ adalah preferensi untuk masing-masing kombinasi atribut. Setiap responden diminta untuk memberikan taraf preferensinya pada masing-masing variabel hasil kombinasi tiga variabel.

Preferensi konsumen didefinisikan sebagai tingkat kesukaan konsumen terhadap sebuah kombinasi atribut buah-buahan. Kombinasi atribut buah-buahan terdiri dari 16 kombinasi atribut. Responden diminta menilai tingkat kesukaan dari setiap 16 kombinasi atribut tersebut yaitu dengan memberikan skala rating 1 sampai 10. Misalnya pada baris 1 (JAP1, Tabel 2), responden diminta menilai tingkat kesukaan terhadap buah pisang lokal dengan budidaya non-organik. Responden harus memilih salah satu skala penilaian dari 1 sampai 10.

Variabel independen adalah jenis buah, asal buah, dan budidaya buah. Variabel independen diukur dengan skala nomimal karena setiap variabel independen tersebut bersifat kategori. Penjelasan lanjut variabel independen disampaikan pada bagian analisis data berikut.

Prosedur pengambilan data dilakukan sebagai berikut. Tahap pertama dari pengambilan data adalah penjelasan kepada para mahasiswa bahwa mereka diminta berpartisipasi untuk mengisi sebuah kuesioner tentang persepsi dan preferensi terhadap buah-buahan. Penjelasan ini dilakukan sekitar 30 menit sebelum kuliah berakhir. Selanjutnya dijelaskan isi kuesioner dan cara mengisi kuesioner tersebut. Tahap kedua, mahasiswa diminta mengisi kuesioner sendiri melalui online. Peneliti memberikan penjelasan terhadap berbagai pertanyaan yang diajukan mahasiswa terkait kuesioner yang diisi. Jumlah responden yang mengisi kuesioner adalah 319 mahasiswa.

Analisis data preferensi konsumen terhadap berbagai kombinasi atribut buah-buahan menggunakan Conjoint Analysis. Analisa 
Conjoint adalah suatu teknik menentukan tingkat kepentingan yang relatif dari berbagai atribut dan taraf suatu produk berdasarkan persepsi responden terhadap preferensi berbagai atribut dan tarafnya tersebut. Preferensi terhadap berbagai atribut tersebut juga menggambarkan kegunaan atau nilai guna dari setiap atribut dan tarafnya. Dalam penelitian ini, produk yang dievaluasi responden adalah buah-buahan. Model Conjoint dapat dituliskan sebagai berikut:

$$
U(X)=\sum_{i=1}^{m} \sum_{j=1}^{k_{i}} \beta_{i j} x_{i j}
$$

keterangan:

$$
\begin{aligned}
& U(X) \quad \text { : Utility total atau preferensi }(Y) \\
& \text { Bij : Part worth atau nilai kegunaan dari } \\
& \text { atribut ke- } i \text { taraf ke-j } \\
& k_{i} \quad: \text { Jumlah kategori (taraf/level) dari } \\
& \text { atribut ke i } \\
& m \quad \text { : Jumlah atribut } \\
& \text { xij : Dummy variable atribut ke-i taraf ke-j } \\
& \text { (bernilai } 1 \text { bila taraf yang berkaitan } \\
& \text { muncul dan } 0 \text { bila tidak) }
\end{aligned}
$$

Untuk menentukan tingkat kepentingan atribut ke- $i$ (Ai) ditentukan melalui formula berikut:

$$
W_{i}=\frac{I_{i}}{\sum_{i=1}^{m} I_{i}} \times 100 \%
$$

keterangan:

li : $(\max (\beta i j)-\min (\beta i j))$, untuk setiap $i$

Nilai guna atau utility total $U(X)$ dapat diprediksi dengan menggunakan regresi berganda dengan variabel dummy. Variabel dependen dalam persamaan regresi tersebut adalah preferensi terhadap atribut ke-i dan taraf ke-j. Sementara itu, independen variabel sebagai prediktor preferensi tersebut adalah variabel dummy (Tabel 1).

Responden mengevaluasi tiga atribut dengan taraf/kategorinya masing-masing. Setiap atribut adalah sebuah variabel independen dengan skala pengukurannya adalah skala nominal. Variabel nominal dapat diubah menjadi variabel skala rasio dengan mengubahnya menjadi variabel dummy. Setiap atribut atau nominal independen variabel akan berubah menjadi beberapa variabel independen dummy bergantung berapa kategori yang dimiliki variabel tersebut. Jumlah variabel dummy adalah jumlah kategori dari atribut dikurangi dengan satu. Variabel dummy ini kemudian masuk ke dalam persamaan regresi sebagai variabel independen atau prediktor dari preferensi.
Tabel 1 Variabel dummy sebagai variabel independen pada persamaan regresi berganda

\begin{tabular}{lcccccc}
\hline & JB1 & JB2 & JB3 & AB & BD & Y \\
\hline Kombinasi 1 & 1 & 0 & 0 & 1 & 0 & \\
Kombinasi 2 & 1 & 0 & 0 & 1 & 1 & \\
Kombinasi 3 & 1 & 0 & 0 & 0 & 0 & \\
Kombinasi 4 & 1 & 0 & 0 & 0 & 1 & \\
Kombinasi 5 & 0 & 1 & 0 & 1 & 0 & \\
Kombinasi 6 & 0 & 1 & 0 & 1 & 1 & \\
Kombinasi 7 & 0 & 1 & 0 & 0 & 0 & \\
Kombinasi 8 & 0 & 1 & 0 & 0 & 1 & \\
Kombinasi 9 & 0 & 0 & 1 & 1 & 0 & \\
Kombinasi 10 & 0 & 0 & 1 & 1 & 1 & \\
Kombinasi 11 & 0 & 0 & 1 & 0 & 0 & \\
Kombinasi 12 & 0 & 0 & 1 & 0 & 1 & \\
Kombinasi 13 & 0 & 0 & 0 & 1 & 0 & \\
Kombinasi 14 & 0 & 0 & 0 & 1 & 1 & \\
Kombinasi 15 & 0 & 0 & 0 & 0 & 0 & \\
Kombinasi 16 & 0 & 0 & 0 & 0 & 1 & \\
\hline
\end{tabular}

Atribut jenis buah memiliki 4 kategori atau taraf, maka atribut jenis buah diubah menjadi tiga variabel independen dummy (4 kategori 1). Variabel jenis buah diberi tanda JB, sehingga dummy variabelnya menjadi JB1, JB2, dan JB3 (JB1=1, jika responden menilai kategori buah pisang; JB2 $=1$, jika responden menilai kategori buah jeruk; JB3 $=1$, jika responden menilai kategori buah semangka; $\mathrm{JB} 1=0, \mathrm{JB} 2=0, \mathrm{JB} 3=0$, jika responden menilai kategori buah lainnya).

Asal buah memiliki dua kategori yaitu lokal dan asing, maka variabel independen asal buah akan diubah menjadi sebuahvariabel independen dummy (jumlah kategori - 1). Variabel asal buah diberi tanda $A B(A B=1$, jika responden menilai kategori buah lokal; $A B=0$, jika responden menilai kategori buah asing).

Budidaya memiliki dua kategori yaitu organik dan nonorganik, maka variabel independen "budidaya" akan diubah menjadi sebuahvariabel independen dummy(jumlah kategori - 1). Variabel budidaya diberi tanda $\mathrm{BD}(\mathrm{BD}=1$, jika responden menilai kategori buah organik; $\mathrm{BD}=0$, jika responden menilai kategori buah nonorganik).

\section{HASIL}

\section{Karakteristik Responden}

Tabel 2 menunjukkan karakteristik sosial ekonomi dan demografi responden. Dari 391 responden, sekitar 59,0 persen dari responden adalah laki-laki dan sisanya adalah perempuan sekitar 41,0 persen. 
Tabel 2 Sebaran responden berdasarkan pendapatan per bulan

\begin{tabular}{llr}
\hline \multicolumn{1}{c}{ Karakteristik } & $\mathrm{N}$ & $\%$ \\
\hline Pendapatan per bulan & & \\
- Data tidak tersedia & 70 & 17,9 \\
- SRp2.000.000,00 & 57 & 14,6 \\
- Rp2.100.000,00-Rp4.000.000,00 & 38 & 9,7 \\
- Rp4.100.000,00-Rp6.000.000,00 & 37 & 9,5 \\
- Rp6.100.000,00-Rp8.000.000,00 & 31 & 7,9 \\
- Rp8.100.000,00-Rp10.000.000,00 & 26 & 6,6 \\
- Rp10.100.000,00-Rp15.000.000,00 & 33 & 8,4 \\
- Rp15.100.000,00-Rp20.000.000,00 & 27 & 6,9 \\
- Rp20.100.000,00-Rp25.000.000,00 & 19 & 4,9 \\
- Rp25.100.000,00-Rp30.000.000,00 & 17 & 4,3 \\
- >Rp30.000.000,00 & 36 & 9,2 \\
\hline
\end{tabular}

Sebagian besar responden $(55,0 \%)$ masih berstatus belum menikah. Jumlah responden yang berstatus bekerja dan mahasiswa paruh waktu adalah sekitar 62,0 persen, sedangkan sisanya sekitar 38,0 persen. Responden yang telah bekerja mengikuti kuliah pada sore hari sampai malam mulai hari senin sampai kamis. Sementara itu, responden yang berstatus mahasiswa penuh waktu mengikuti kuliah pada hari dan jam kerja yaitu mulai pukul 8 sampai 17 dari hari senin sampai hari jumat. Tabel 2 juga menunjukkan sebaran responden berdasarkan pendapatan mahasiswa per bulan. Sekitar 33,0 persen dari responden memiliki pendapatan lebih dari Rp10.000.000,00 per bulan, sedangkan mayoritas sekitar 67,0 persen berpendapatan kurang dari Rp10.000.000,00 per bulan.

\section{Preferensi terhadap berbagai atribut buah- buahan}

Preferensi terhadap buah-buahan diukur dengan meminta responden untuk memberikan sebuah skala preferensi antara skala 1 sampai 10 untuk setiap kombinasi atribut dari buah-buahan. Tabel 3 menunjukkan 16 kombinasi dari 3 atribut buahbuahan yang harus diberikan skala preferensinya oleh responden. Tabel 3 menunjukkan nilai rata-rata dari setiap kombinasi tersebut diurutkan berdasarkan nilai rataan preferensi yang tertinggi.

Empat nilai rataan preferensi tertinggi didapatkan dari atribut buah-buahan dengan budidaya organik dan asal buah lokal. Sedangkan peringkat berikutnya adalah nilai rataan preferensi terhadap atribut buah dengan budidaya organik dan buah asing. Berdasarkan Tabel 3 tersebut dapat disimpulkan bahwa responden sangat menyukai pisang lokal yang dibudidayakan secara organik, kemudian peringkat berikutnya adalah buah lainnya yang berasal dari lokal dan dibudidayakan secara organik. Peringkat preferensi ketiga adalah buah jeruk lokal yang dibudidayakan secara organik.

Tabel 3 Nilai rataan preferensi terhadap 16 kombinasi atribut buah-buahan

\begin{tabular}{lcccr}
\hline \multicolumn{1}{c}{ Nama Variabel } & Jenis & Asal & Budidaya & Yi (Preferensi) \\
\hline JAP2 & Pisang & Lokal & Organik & 6,7744 \\
JAP14 & Lainnya & Lokal & Organik & 6,7282 \\
JAP6 & Jeruk & Lokal & Organik & 6,5231 \\
JAP10 & Semangka & Lokal & Organik & 6,5205 \\
JAP16 & Lainnya & Asing & Organik & 6,0051 \\
JAP4 & Pisang & Asing & Organik & 5,9615 \\
JAP12 & Semangka & Asing & Organik & 5,9275 \\
JAP8 & Jeruk & Asing & Organik & 5,9205 \\
JAP1 & Pisang & Lokal & Non-organik & 5,8487 \\
JAP13 & Lainnya & Lokal & Non-organik & 5,8256 \\
JAP5 & Jeruk & Lokal & Non-organik & 5,7487 \\
JAP9 & Semangka & Lokal & Non-organik & 5,7436 \\
JAP15 & Lainnya & Asing & Non-organik & 5,3513 \\
JAP11 & Semangka & Asing & Non-organik & 5,2872 \\
JAP7 & Jeruk & Asing & Non-organik & 5,2667 \\
JAP3 & Pisang & Asing & Non-organik & 5,2436 \\
\hline
\end{tabular}




\section{Faktor-Faktor yang Memengaruhi Preferensi terhadap Buah-Buahan}

Tabel 4 memperlihatkan hasil regresi berganda untuk menganalisis pengaruh atribut buah-buahan terhadap preferensi buahbuahan. Variabel dependen dalam model regresi berganda tersebut adalah preferensi terhadap buah-buahan. Variabel independen terdiri atas lima variabel. Kelima variabel independen tersebut adalah variabel dummy seperti telah dijelaskan pada bagian metode. Variabel independen yang pertama adalah buah pisang vs buah lainnya. Variabel independen yang kedua adalah buah jeruk vs buah lainnya. Variabel independen yang ketiga adalah semangka vs buah lainnya. Variabel independen yang keempat adalah buah lokal vs buah impor. Variabel independen yang kelima adalah buah organik vs buah nonorganik. Kombinasi variabel dependen dan independen dalam model regresi berganda untuk analisis preferensi konsumen pada studi ini dapat dilihat pada Tabel 4.

Koefisien dari setiap variabel independen menggambarkan perbedaan nilai preferensi antara independen variabel tersebut dengan variabel yang menjadi variabel dasar. Tabel 3 memperlihatkan dua macam koefisien yaitu $B$ (unstandardized coefficient) dan $\beta$ (standardized coefficients). Kedua koefisien tersebut menunjukkan perubahan variabel dependen akibat adanya perubahan setiap unit variabel independen. Apabila unit pengukuran setiap independen variabel berbeda maka nilai koefisien B dari setiap variabel independen tidak dapat diperbandingkan. Untuk mengatasi hal tersebut maka dilakukan transformasi variabel menjadi data terstandarisasi yaitu data pada setiap variabel yang memiliki nilai rataan 0 (nol) dan nilai ragam 1 . Koefisien yang dihasilkan dari data yang terstandardisasi adalah nilai koefisien Beta. Nilai koefisien Beta menunjukkan nilai standar deviasi dari variabel dependen yang berubah akibat perubahan satu standar deviasi dari sebuah sebuah independen variabel. Interpretasi berikut berdasarkan nilai koefisien beta. Dari hasil analisis regresi menunjukkan koefisien beta variabel buah pisang bernilai negatif dan tidak signifikan. Ini artinya variabel pisang tidak berpengaruh terhadap preferensi atau tidak ada perbedaan preferensi terhadap buah pisang dengan preferensi terhadap buah lainnya. Demikian pula koefisien beta buah jeruk memiliki nilai negatif dan tidak signifikan. Ini artinya variabel buah jeruk tidak berpengaruh terhadap preferensi yaitu tidak ada perbedaan preferensi terhadap buah jeruk dengan preferensi terhadap buah lainnya. Koefisien beta buah semangka juga menunjukkan nilai negatif dan tidak signifikan. Ini artinya bahwa variabel buah semangka tidak berpengaruh terhadap preferensi yaitu tidak ada perbedaan preferensi terhadap buah semangka dengan preferensi terhadap buah lainnya.. Ketiga variabel independen tersebut adalah variabel dummy yang artinya memiliki nilai dua kategori, yaitu nilai 1 dan nilai 0 , sehingga koefisien beta dari buah pisang tersebut menujukkan perbedaan nilai preferensi antara preferensi buah pisang dengan buah lainnya.

Tabel 4 Kombinasi variabel dependen dan independen dalam model regresi berganda untuk analisis preferensi konsumen

\begin{tabular}{|c|c|c|c|c|c|c|}
\hline \multirow{2}{*}{\multicolumn{2}{|c|}{ Variabel }} & \multicolumn{2}{|c|}{$\begin{array}{c}\text { Tidak } \\
\text { Tersandarisasi } \\
\end{array}$} & \multirow{2}{*}{$\begin{array}{c}\text { Terstandarisasi } \\
\text { Beta }\end{array}$} & \multirow{2}{*}{$t$} & \multirow{2}{*}{ Sig. } \\
\hline & & B & $\begin{array}{l}\text { Std. } \\
\text { Error }\end{array}$ & & & \\
\hline 1 & (Constant) & 5,303 & 0,079 & & 67,309 & 0,000 \\
\hline JB1 & $\begin{array}{l}\text { Pisang vs buah lainnya ( } 1=\text { Jika } \\
\text { memilih Pisang, } 0=\text { memilih buah } \\
\text { lainnya) }\end{array}$ & $-0,021$ & 0,091 & $-0,003$ & $-0,225$ & 0,822 \\
\hline JB2 & $\begin{array}{l}\text { Jeruk vs buah lainnya }(1=\text { Jika } \\
\text { memilih Jeruk, } 0=\text { memilih buah } \\
\text { lainnya) }\end{array}$ & $-0,113$ & 0,091 & $-0,019$ & $-1,240$ & 0,215 \\
\hline JB3 & $\begin{array}{l}\text { Semangka vs buah lainnya ( } 1=\text { Jika } \\
\text { memilih Semangka, } 0=\text { memilih buah } \\
\text { lainnya) }\end{array}$ & $-0,123$ & 0,091 & $-0,021$ & $-1,353$ & 0,176 \\
\hline$A B$ & $\begin{array}{l}\text { Buah lokal vs buah impor ( } 1=\text { jika } \\
\text { memilih buah lokal, } 0=\text { jika memilih } \\
\text { buah impor) }\end{array}$ & 0,601 & 0,064 & 0,116 & 9,347 & 0,000 \\
\hline $\mathrm{BD}$ & $\begin{array}{l}\text { Buah organik vs buah non-organik } \\
(1=\text { jika memilih buah organik, } 0=\text { jika } \\
\text { memilih buah non-organik) }\end{array}$ & 0,748 & 0,064 & 0,145 & 11,629 & 0,000 \\
\hline
\end{tabular}


Berdasarkan uji statistik pada taraf 5,0 persen, menunjukkan bahwa ketiga variabel dummy jenis buah-buahan tersebut tidak berbeda nyata, sehingga koefisien negatif tersebut menunjukkan tidak ada perbedaan preferensi antara preferensi terhadap buah pisang dengan buah lainnya. Demikian pula tidak ada perbedaan preferensi antara buah jeruk dengan buah lainnya, dan tidak ada perbedaan antara preferensi buah semangka dengan buah lainnya. Variabel independen keempat dalam model regresi berganda adalah $A B$ yaitu buah lokal vs buah impor yang memiliki koefisien beta positif dan signifikan. Ini artinya preferensii terhadap buah lokal lebih besar dibandingkan terhadap buah impor, konsumen lebih menyukai buah lokal dibandingkan buah impor. Variabel independen kelima adalah BD yaitu buah organik vs buah non-organik yang memiliki koefisien beta positif dan signifikan. Ini menunjukkan bahwa preferensi terhadap buah organik lebih tinggi dari buah non-organik. Konsumen lebih menyukai buah organik dibandingkan dengan buah non-organik.

\section{Analisis Konjoin Tingkat Preferensi terhadap Jenis Buah, Asal Buah, dan Budidaya Buah}

Hasil analisis regresi berganda tidak dapat memberikan informasi atribut mana yang dianggap paling penting oleh konsumen apakah atribut jenis buah, asal buah atau cara budidaya. Untuk mendapatkan informasi peringkat preferensi berdasarkan atribut tersebut, maka dilakukan analisis konjoin sebagaimana ditunjukkan pada Tabel 5.

\begin{tabular}{lccc}
$\begin{array}{c}\text { Tabel } 5 \text { Tingkat } \\
\text { berdasarkan analisis konjoin }\end{array}$ & kepentingan \\
\hline $\begin{array}{l}\text { Factor level per } \\
\text { attribute }\end{array}$ & Utility & $\begin{array}{c}\text { Range } \\
\text { of part- } \\
\text { worth }\end{array}$ & $\begin{array}{c}\text { Factor } \\
\text { importance }\end{array}$ \\
\hline Overall & & & \\
\hline $\begin{array}{l}\text { Jenis buah } \\
\text { - Pisang }\end{array}$ & 0,04 & 0,12 & 8,36 \\
- Jeruk & $-0,05$ & & \\
- Semangka & $-0,06$ & & \\
- Buah lainnya & 0,06 & & \\
\hline $\begin{array}{l}\text { Asal buah } \\
\text { - Lokal }\end{array}$ & 0,3 & 0,6 & 40,83 \\
- Impor & $-0,03$ & & \\
\hline $\begin{array}{l}\text { Budidaya buah } \\
\text { - Organik }\end{array}$ & 0,37 & 0,75 & 50,8 \\
- Non-organik & $-0,37$ & & \\
\hline $\begin{array}{l}\text { Sum of part- } \\
\text { worth }\end{array}$ & & 1,47 & \\
\hline
\end{tabular}

Tabel 5 menunjukkan hasil analisis konjoin. Kolom pertama menunjukkan tiga atribut dari buah-buahan yang dievaluasi responden. Atribut pertama adalah jenis buah-buahan yang memiliki empat level atau 4 jenis buahbuahan yang dievaluasi tingkat preferensinya oleh responden yaitu pisang, jeruk, semangka, dan buah lainnya. Atribut kedua adalah asal buah-buahan yang memiliki dua level atau dua macam sumber buah-buahan yaitu buah lokal dan buah impor. Atribut ketiga adalah budidaya buah-buahan yang memiliki dua level atau dua macam budidaya yaitu buah-buahan organik dan nonorganik.

Kolom kedua menunjukkan utility yaitu menggambarkan preferensi responden terhadap sebuah level dari setiap atribut dari objek (buah-buahan) yang dinilainya. Nilai utility diperoleh dengan mengurangi rata-rata nilai preferensi terhadap sebuah level dari setiap atribut dengan nilai preferensi keseluruhan. Nilai utility dari pisang adalah 0,04 , nilai ini menggambarkan perbedaan atau deviasi dari pereferensi keseluruhan. Nilai rata-rata preferensi terhadap pisang adalah 5,95 , sedangkan nilai rata-rata preferensi keseluruhan adalah 5,91. Nilai utility diperoleh dengan mengurangi nilai rata-rata preferensi terhadap pisang dengan nilai rata-rata preferensi keseluruhan. Nilai utility positif menunjukkan bahwa nilai preferensi terhadap sebuah level dari atribut adalah lebih besar dari nilai preferensi keseluruhan. Nilai utility negatif menunjukkan bahwa nilai preferensi terhadap sebuah level dari atribut memperlihatkan nilai preferensi keseluruhan.

Kolom ketiga pada Tabel 5 adalah part-worth yaitu menggambarkan utility dari setiap level dari sebuah atribut. Jadi nilai utility dari pisang sama dengan nilai part-worth dari pisang tersebut. Range of parth-worth dari sebuah atribut adalah perbedaan nilai utility (partworth) dari sebuah level dengan nilai utility terbesar dengan sebuah level dengan nilai utility terkecil. Tabel 4 menunjukkan bahwa nilai range part-worth dari atribut jenis buah adalah 0,12. Nilai ini diperoleh dengan mengurangi nilai utility buah lainnya (nilai terbesar dari level pada atribut jenis buah) dengan nilai utility semangka (nilai terkecil dari level pada atribut jenis buah), yaitu 0,06-($0,06)=0,12$. Selanjutnya nilai range of parthworth dari setiap atribut dijumlahkan sehingga menghasilkan nilai 1,47 , nilai ini disebut sum of part-worth.

Kolom keempat pada Tabel 5 menunjukkan factor atau atribut importance. Nilai ini 
diperoleh dengan membandingkan nilai range of part-worth dari setiap atribut dengan sum of part-worth kemudian dikalikan dengan 100 . Berdasarkan Tabel 4 diperoleh nilai importance dari atribut jenis buah-buahan adalah 8,4 persen, kemudian 40,8 persen untuk nilai importance dari atribut asal buah, dan 50,8 persen untuk nilai importance dari atribut budidaya buah-buahan. Nilai importance dari atribut memiliki arti bahwa semakin besar nilai tersebut menunjukkan bahwa atribut tersebut dinilai lebih penting dari atribut lainnya.

\section{PEMBAHASAN}

Dalam penelitian ini, responden diminta untuk memberikan nilai preferensi terhadap empat macam buah-buahan yaitu pisang, jeruk, semangka, dan buah lainnya. Jika responden memberikan nilai preferensi terhadap jenis buah diluar ketiga yang disebutkan tersebut maka responden diminta untuk menyebutkan nama buah yang dinilai tersebut. Sehingga variabel jenis buah dibagi menjadi tiga variabel dummy. Berdasarkan hasil uji regresi berganda (Tabel 4 yaitu nilai t hitung untuk variabel pisang, jeruk, dan semangka tidak signifikan pada taraf 5 persen. Ini menunjukkan bahwa bahwa tiga variabel independen tersebut tidak berpengaruh terhadap preferensi buah-buahan, Ini menunjukkan bahwa tidak ada perbedaan tingkat preferensi antar jenis buah-buahan tersebut. Responden tampaknya memiliki keragaman jenis buah-buahan yang disukainya.Tidak ada responden yang menunjukkan nilai preferensi yang lebih tinggi dari satu buah dibandingkan dengan buah lainnya.Ini menunjukkan keragaman preferensi dari konsumen. Konsumen menyukai beragam jenis buah-buahan.

Independen variabel berikutnya adalah buah lokal. Variabel ini membandingkan antara buah lokal dengan buah impor. Hasil uji regresi berganda menunjukkan koefisien beta variabel buah lokal memiliki nilai positif dan signifikan pada tingkat 1,0 persen. Ini menunjukkan bahwa variabel buah lokal berpengaruh terhadap preferensi yaitu nilai preferensi terhadap buah lokal lebih tinggi dibandingkan buah impor. Artinya responden lebih menyukai buah lokal dibandingkan dengan buah impor. Hasil analisis ini menunjukkan bahwa walaupun buah-buahan impor tersedia diberbagai tempat di Indonesia dan dikonsumsi oleh sebagian besar konsumen Indonesia, namun konsumen lebih menyukai buah lokal dibandingkan dengan buah impor.
Hasil ini selaras dengan penelitian Brown (2003), bahwa kosumen yang memilki pendapatan dan pendidikan yang lebih baik cenderung memiliki keinginan yang lebih kuat untuk membayar lebih produk lokal dan produk organik. Hal ini memperlihatkan bahwa pendidikan dan pengetahuan konsumen menjadi faktor penting terciptanya pembangunan yang berkelanjutan (sustainability).

Data nasional (BPS, 2016; FAOSTAT, 2016) menunjukan konsumen Indonesia cukup banyak mengkonsumsi buah impor. Faktor ketersediaan dapat menjadi alasan bagi konsumen untuk mengonsumsi buah impor apabila buah lokal tidak tersedia di pasar. Artinya apabila buah lokal tidak tersedia maka ia akan beralih ke buah impor. Data nasional mencatat bahwa 25,0 persen jeruk atau sebanyak hampir 200 ribu ton yang dikonsumsi orang Indonesia pada tahun 2014 adalah impor (BPS, 2015b; FAOSTAT 2016). Bahkan lebih dari 80,0 persen apel yang dikonsumsi domestik berasal dari impor (BPS, 2016; FAOSTAT, 2016). Oleh karena itu sangat penting petani harus selalu memproduksi buah-buahan lokal karena ketersediaan akan mendorong konsumen juga menyukai buah lokal.

Sumber daya alam yang luar biasa ini menyediakan potensi alam yang sangat besar bagi penduduknya. Wilayah Indonesia yang terbentang di area tropis dengan suhu yang tinggi $\left(21-33^{\circ} \mathrm{C}\right)$, kelembaban yang tinggi (70$90 \%$ ), dan curah hujan yang sangat tinggi membuat wilayah ini sesuai untuk bercocok tanam hingga 3 kali rotasi per tahun, terutama di daerah subur seperti Jawa dan Bali. Figur alam yang luar biasa tersebut memberikan kesempatan bagi Indonesia untuk banyak menghasilkan produk pertanian tropis termasuk buah-buahan tropis yang sangat beraneka ragam. Namun demikian, sistem manajemen yang belum baik dan efisien serta infrastruktur yang belum mendukung membuat biaya produksi per satuan produk cukup tinggi. $\mathrm{Hal}$ ini membuat harga buah lokal lebih mahal apabila dibandingkan dengan buah impor untuk kualitas yang setara. Apabila fenomena ini terjadi terus menerus tanpa ada usaha untuk mencari solusi maka produk buah lokal Indonesia akan semakin menurun daya saingnya. Bahkan bila berlanjut, usaha produk buah lokal akan semakin kalah bersaing dengan buah impor.

Variabel independen ketiga adalah buah organik, yang membandingkan buah organik 
dan buah non-organik. Hasil regresi berganda menunjukkan bahwa koefisien beta bernilai positif dan signifikan yang berarti variabel buah organik berpengaruh terhadap preferensi buah-buahan. Ini menunjukkan bahwa responden lebih menyukai buah organik dibandingkan buah non-organik. Responden lebih menyukai buah organik dibandingkan non-organik. Tingkat preferensi buah organik yang lebih tinggi dari buah non-organik menunjukkan bahwa konsumen memiliki pengetahuan mengenai buah organik yang dianggap lebih baik dari segi kesehatan sehingga ia menyukai buah organik. Data ini memberikan implikasi penting bahwa di masa depan, budidaya buah-buahan harus mempertimbangkan cara budidaya organik karena para konsumen akan lebih memperhatikan kesehatan dari buah-buahan yang dikonsumsinya.

Semua responden adalah mahasiswa artinya mereka berpendidikan tinggi, sehingga mereka memiliki pengetahuan yang tinggi dan kesadaran yang tinggi tentang pentingnya dan lebih baiknya buah-buahan organik. Konsumen yang berpendidikan tinggi lebiht mudah terpapar informasi mengenai buah organik sehingga meningkatkan pengetahuan mereka tentang buah organik. Pengetahuan tersebut telah mendorong dan meningkatkan preferensi terhadap buah-buahan organik. Pengetahuan berkorelasi positif terhadap kepedulian akan aspek organik dan asal buah produk (Brown, 2013).

Hasil analisis regresi menunjukkan pengaruh setiap variabel independen terhadap tingkat preferensi buah-buahan. Analisis regresi memperlihatkan preferensi responden terhadap masing-masing atribut dan level atribut dari buah-buahan, yaitu preferensi terhadap setiap jenis buah: pisang, jeruk, semangka dan buah lainnya. Hasil regresi selanjutnya menunjukkan preferensi terhadap atribut asal buah, yaitu preferensi buah lokal dan buah impor serta preferensi terhadap atribut budidaya buah-buahan yaitu preferensi terhadap buah organik dan non-organik. Setelah melakukan analisis regresi, selanjutnya melakukan analisis konjoin. Analisis konjoin atau tabel konjoin diperoleh berdasarkan nilai koefisien (unstandardized coeficients) dari setiap independen variabel pada regresi berganda. Analisis konjoin akan memberikan informasi tingkat kepentingan dari setiap atribut pada levelnya atau tarafnya masing-masing sehingga dapat membandingkan tingkat kepentingan antar atribut.
Hasil analisis conjoint pada Tabel 5 menggambarkan atribut yang lebih disukai atau lebih penting. Dari ketiga atribut yang dinilai, atribut budidaya dianggap paling penting dipertimbangkan responden saat memilih buah-buahan, selanjutnya atribut asal buah-buahan, dan terakhir adalah jenis buahbuahan. Tabel 5 juga menunjukkan level mana dari setiap atribut yang lebih disukai oleh responden. Dari atribut jenis buah-buahan, jenis buah lainnya lebih disukai oleh responden. Ini artinya sebagian besar responden memilih buah lainnya sebagai jenis buah yang lebih disukai. Jenis buah berikutnya yang disukai adalah pisang, kemudian jeruk dan semangka. Sebagai salah satu negara tropis dengan tingkat biodiversitas tertinggi di dunia, Indonesia sangat berpotensi untuk menjadi produsen buah terbesar di dunia, terutama untuk buah-buahan khas tropis (FAOSTAT, 2016; WB WDI, 2015). Potensi produksi buah domestik Indonesia sangat tinggi dan diprediksi mampu untuk memenuhi permintaan pasar domestik akan buah.

Hasil analisis juga menunjukkan bahwa buah lokal lebih disukai dari buah impor ini ditunjukkan nilai utility dari buah lokal lebih tinggi dari buah impor. Beberapa penelitian terdahulu yang relevan dengan hasil penelitian inidikemukakan oleh Anggasari, Yuliati, dan Retnaningsih (2013) dan Monalisa (2015) yang menganalisis pengaruh etnosentrisme terhadap preferensi buah impor dan lokal. Beberapa penelitian lain membandingkan preferensi antara buah lokal dan impor tanpa mengkaitkannya dengan variabel etnosentrismen (Savitri, Yusuf, \& Suardi, 2016; Sadeli \& Utami, 2013; Widiyanto, Adhi, \& Daryanto, 2016; Sukmaningtyas \& Hartoyo, 2013). Sebagian hasil penelitian Sukmaningtyas dan Hartoyo (2013) sejalan dengan penelitian ini, yaitu sekitar 70 persen responden lebih menyukai jeruk lokal dibandingkan jeruk impor. Sungkawa, Purnomo, dan Fauziah (2015) menunjukkan bahwa sekitar 66,0 persen dari responden bahwa preferensi konsumen terhadap buah lokal karena faktor ketersediaan buah lokal. Beberapa hasil penelitian lainnya tidak konsisten dengan hasil penelitian ini. Rajagukguk, Sayekti, dan Situmorang (2013) menemukan bahwa jeruk impor lebih disukai dari jeruk lokal. Sadeli dan Utami (2013) juga menemukan bahwa responden lebih menyukai jeruk impor dibandingkan jeruk lokal. Widiyanto, Adhi, dan Daryanto (2016) menunjukkan bahwa responden lebih menyukai apel impor dibandingkan apel lokal. Anggasari, Yuliati, dan Retnaningsih (2013) 
dan Monalisa (2015) menunjukkan bahwa kesukaan terhadap buah lokal sangat dipengaruhi tingkat etnosentrisme dari reponden, semakin tinggi tingkat etnosentrisme maka semakin besar kesukaan responden terhadap buah lokal.

Hasil penelitian menunjukkan bahwa nilai utility dari buah organik lebih tinggi dari buah non-organik, artinya responden lebih menyukai buah-buahan organik dibandingkan nonorganik. Studi ini membuktikan sebagian konsumen menganggap asal dan cara budidaya (organik) buah menjadi aspek penting dalam membeli buah. Studi Hempel dan Hamm (2016) di Jerman menemukan bahwa konsumen yang memperhatikan aspek cara budidaya (organik), juga lebih memperhatikan asal buah produk. Keinginan mengonsumsi produk organik dan lokal dipengaruhi pengetahuan pentingnya kedua aspek tersebut untuk kelestarian lingkungan dan kualitas kehidupan berkelanjutan. Hasil studi yang sama dikemukakan Meas et al. (2015) bahwa konsumen organik memiliki kepedulian yang lebih terhadap aspek asal buah produk. Hal ini karena konsumen organik memiliki pengetahuan lebih baik tentang mengonsumsi produk lokal untuk meningkatkan perekonomian domestik (Meas et al., 2015; Kalabova, Mokry, \& Turcinkova, 2013). Pengetahuan konsumen merupakan salah faktor penting dalam pembangunan yang berkelanjutan.

Hasil penelitian ini membuktikan bahwa konsumen lebih menyukai buah lokal dan organik dibandingkan buah impor dan buah non-organik. Hasil penelitian ini sangat relevan dengan program Pemerintah Republik Indonesia yang sedang mengukur Keberdayaan Konsumen. Salah satu indikator dari keberdayaan konsumen adalah konsumsi produk nasional termasuk buah-buahan nasional. Keberdayaan Konsumen didefinisikan sebagai Perspektif kesadaran, pemahaman dan kemampuan diukur melalui tiga dimensi dalam interaksi pasar yaitu sebelum pembelian, saat pembelian dan pasca pembelian (Direktorat Perlindungan Konsumen, 2015). Ada tiga indikator keberdayaan pada dimensi pembelian yaitu Keberdayaan Konsumen Saat Pembelian yaitu: a) Pemilihan barang/jasa (harga, bunga, label dsb), b) Perilaku pembelian (pengecekan terhadap barang/jasa, klausula baku dsb) dan c) Kecintaan produk dalam negeri (Direktorat Perlindungan Konsumen, 2015). Berdasarkan konsep keberdayaan konsumen, hasil penelitian ini memperlihatkan keberdayaan konsumen relatif tinggi dari aspek kecintaan produk dalam negeri karena hasil penelitian menunjukkan bahwa responden lebih menyukai produk lokal atau produk nasional.

Para podusen buah lokal atau nasional harus didorong untuk berproduksi agar dapat menyediakan buah lokal secara berkesinambungan. Para produsen buah lokal harus mulai memproduksi buah-buahan organik sehingga mampu menyediakan buah organik lebih banyak di pasar. Hasil penelitian ini memberikan implikasi penting terhadap pendidikan konsumen di Indonesia. Pendidikan Konsumen harus diarahkan untuk memperkuat program pendidikan konsumen cinta produk buah-buahan nasional. Hasil penelitian menunjukkan bahwa responden masih menyukai produk buah-buahan nasional. Kecintaan terhadap produk nasional harus tetap ditumbuhkan karena produk impor akan melakukan promosi besar-besaran agar produknya disukai konsumen Indonesia. Oleh sebab itu, kampanye cinta produk nasional harus tetap diintensifkan agar tidak tertutupi oleh kampanye produk impor. Salah satu cara kampanye tersebut adalah melalui pendidikan konsumen cinta produk nasional. Melalui pendidikan konsumen rasa cinta produk nasional dapat ditumbuhkan serta sosialisasi produk produk organik buah-buahan dapat dilakukan, sehingga konsumen memiliki pengetahuan yang baik mengenai manfaat produk organik serta konsumen dapat mengetahui alasan mengapa harus mencintai produk nasional.

\section{SIMPULAN DAN SARAN}

Tujuan pertama penelitian ini adalah untuk menganalisis faktor-faktor yang memengaruhi preferensi terhadap buah-buahan. Hasil penelitian menunjukkan bahwa variabel jenis buah-buahan tidak berpengaruh terhadap preferensi, yaitu tidak ada perbedaan preferensi terhadap buah pisang, jeruk, semangka dan buah lainnya. Variabel buah lokal dan buah organik berpengaruh terhadap preferensi, artinya preferensi terhadap buah lokal dan buah organik lebih lebih tinggi dibandingkan preferensi terhadap buah impor dan buah non-organik.

Tujuan kedua dari penelitian ini adalah mengukur preferensi konsumen terhadap tiga atribut buah-buahan yaitu jenis buah, asal buah (lokal dan impor), serta cara budidaya buah (organik dan non-organik), serta menentukan atribut apa yang lebih disukai oleh konsumen dengan menggunakan analisis 
konjoin. Hasil analisis konjoin diperoleh setelah melakukan tahap analisis regresi. Analisis regresi adalah landasan dari analisis konjoin. Hasil analisis konjoin menunjukkan bahwa diantara tiga atribut buah-buahan, maka atribut pertama yang dianggap penting dalam memilih buah-buahan adalah budidaya buah-buahan yaitu responden lebih menyukai buah organik. Atribut kedua yang dianggap penting adalah asal buah-buahan yaitu buah lokal lebih disukai atau dianggap lebih penting dibandingkan buah impor. Atribut ketiga yang dipertimbangkan responden adalah jenis buahbuahan dan responden menunjukkan preferensi yang relatif sama terhadap buahbuahan yang dinilainya.

Penelitian ini berfokus kepada sampel mahasiswa sehingga pendidikan mereka yang tinggi telah menumbuhkan kesadaran cinta produk nasional sehingga responden lebih menyukai produk buah-buahan lokal atau nasional. Penelitian preferensi berikutnya dapat memilih sampel dari masyarakat dengan pendidikan menengah ke bawah dan mereka yang berpendidikan sarjana namun yang sedang tidak melakukan pendidikan S2. Salah satu program penting pendidikan konsumen cinta produk buah-buahan nasional adalah meningkatkan kampanye buah-buahan nasional agar menyadarkan konsumen Indonesia untuk bersedia mengonsumsi buahbuahan nasional. Para produsen buah nasional harus terus diberdayakan agar mereka mampu memproduksi buah nasional dengan baik dan selalu dapat menyediakan buah-buahan sepanjang waktu. Kesinambungan produksi buah-buahan nasional sangat penting agar buah selalu tersedia saat dibutuhkan konsumen. Ketiadaan buah nasional di pasar dapat menjadi penyebab konsumen beralih membeli produk buah impor.

\section{DAFTAR PUSTAKA}

Anggasari, P., Yuliati, L. N., \& Retnaningsih. (2013). Pengaruh ethnosentrisme terhadap sikap, preferensi dan perilaku pembelian buah lokal dan impor. Jurnal Manajemen \& Agribisnis, 10(2), 128136.

[BPS] Badan Pusat Statistik. (2015a). Pengeluaran untuk konsumsi penduduk Indonesia 2015. Diambil dari: https://www.bps.go.id/website/pdf_publik asi/Pengeluaran-Untuk-KonsumsiPenduduk-Indonesia-Berdasarkan-HasilSusenas-September-2015.pdf [diunduh 15 Desember 2016]. (2015b). Statistik Indonesia: Statistical yearbook of Indonesia 2015. Diambil dari: http://www.bps.go.id/website/pdf_publika si/Statistik-Indonesia-2015.pdf [Diunduh 11 Oktober 2015].

. (2016). Laporan bulanan: data sosial ekonomi, edisi desember, 2016. Diambil dari:

https://www.bps.go.id/website/pdf_publik asi/Laporan-Bulanan-Data-Sosial-

Ekonomi-Desember-2016.pdf [Diunduh 15 Desember 2016].

Brown, C. (2003). Consumers' preferences for locally produced food: A study in southeast Missouri. American Journal of Alternative Agriculture, 18, 213-224. doi:10.1079/AJAA200353

Ceulemans, K., Molderez, I., \& Van Liedekerke, L. V. (2015). Sustainability reporting in higher education: a comprehensive review of the recent literature and paths for further research. Journal of Cleaner Production, 106, 127143. doi:10.1016/j.jclepro.2014.09.052.

de Carvalho, B. L., Salgueiro, Md. F., \& Rita, P. (2015). Consumer sustainability consciousness: a five dimensional construct. Ecological Indicators, 68, 402410. doi:10.1016/j.ecolind.2015.05.053.

[FAOSTAT]. (2016). Top 25 export-import commodities in Indonesia. Diambil dari http://faostat3.fao.org/ [diunduh 10 Oktober 2016].

Hadayanti, D., Deliana, Y., \& Natawidjaja, R. S. (2016). Faktor dominan dari preferensi konsumen dalam pemilihan jenis mangga (Mangifera Indica): suatu kasus di supermarket di kota Bandung. Jurnal Agrikultura, 27(2), 94-101.

Hempel, C., \& Hamm, U. (2016). How important is local food to organic-minded consumers?. Appetite, 96, 309-318. doi:10.1016/j.appet.2015.09.036.

Kalabova, J., Mokry, S., \& Turcinkova, J. (2013). Regional differences of consumer preferences when shopping for regional products. Acta Univ. Agric. Silvic. Mendelianae Brun, 61, 22552259.

doi:10.11118/actaun201361072255.

Direktorat Perlindungan Konsumen, Dirjen Standarisasi dan Perlindungan Konsumen, Kemendag RI, (2015). Indeks keberdayaan konsumen. Bahan Presentasi. 
Kohtala, C. (2014). Addressing sustainability in research on distributed production an integrated literature review. Journal of Cleaner Production, 106, 654-668. doi:10.1016/j.jclepro.2014.09.039.

Li, J., Hudson, S. (2016). Conjoint analysis of consumer preferences to destination brand attributes. Amherst Tourism Travel and Research Association: Advancing Tourism Research Globally 2016 International Conference. University of Massachusetts, Massachusetts, Amerika. Diambil dari http://scholarworks.umass.edu/cgi/viewc ontent.cgi ?article $=1255 \&$ context=ttra [diunduh 7 Maret 2017].

Lu, J., Wu, L., Wang, S., \& Xu, L. (2016). Consumer preference and demand for traceable food attributes: a choicebased conjoint analysis. Contributed Paper prepared for presentation at the 90th Annual Conference of the 12 Agricultural Economics Society, University of Warwick, England 13144 6 April 2016. Diambil dai http://www.aes.ac.uk/upload area/memb er documents/Linhai Wu Consumer\%2 OPreference\%20and\%20Demand\%20for $\% 20$ Traceable\%20Food\%20Attributes \% 20A\%20Choice-

based\%20Conjoint\%20Analysis.pdf, [diunduh 7 Maret 2017].

Meas, T., Hu, W., Batte, M. T., Woods, T.A., \& Ernst, S. (2015). Substitutes or complements? consumer preference for local and organic food attributes. Am. J. Agr. Econ, 97(4), 1044-107.

Monalisa, T. (2015). Pengaruh etnosentrisme konsumen kota malang terhadap niat beli buah lokal. Parsimonia, 2(2), 23-33.

Prihatiningtyas, R., Setiawan, A. S., \& Wijaya, N. H. (2015). Analisis peningkatan kualitas pada rantai pasok buah pepaya calina. Jurnal Manajemen \& Organisasi, 6(3), 206-224.

Rahayu, J. N., Fauziyah, E., \& Ariyani, A.H. M. (2012). Preferensi konsumen terhadap buah apel impor di toko buah hokky dan pasar tradisional Ampel Surabaya. Agriekonomika, 1(1), 52-67.

Rajagukguk, M. J., Sayekti, W. D., \& Situmorang, S. (2013). Sikap dan pengambilan keputusan konsumen dalam membeli buah jeruk lokal dan jeruk impor di Bandar Lampung. Jurnal IImu-Ilmu Agribisnis, 1(4), 351-357.
Sadeli, A. H., \& Utami, H. N. (2013). Sikap konsumen terhadap atribut produk untuk mengukur daya saing produk jeruk. Trikonomika, 12(1), 61-71.

Santoso, P. J., Novaril, M., Jawal, A. S., Wahyudi, T., \& Hasyim, A. (2008). Idiotipe durian nasional berdasarkan preferensi konsumen. J. Hort, 18(4), 395-401.

Savitri, M. A. W., Yusuf, R. P., \& Suardi, I. D. P. O. (2016). Preferensi masyarakat dalam membeli jeruk di Kota Denpasar, Bali. E-Jurnal Agribisnis \& Agrowisata, 5(2), 439-448.

Sukmaningtyas, A., \& Hartoyo. (2013). Pengaruh nilai dan gaya hidup terhadap preferensi dan perilaku pembelian buahbuahan impor. Jurnal IImu Keluarga dan Konsumen, 6(1), 39-48. doi: http://dx.doi.org/10.24156/jikk.2013.6.1.3 9.

Sungkawa, I., Purnomo, D., \& Fauziah. E. (2015). Hubungan antara persepsi dan preferensi konsumen dengan pengambilan keputusan pembelian buah lokal (studi kasus di pasar harjamukti, pasar pagi, dan pasar kanoman, Kota Cirebon). Jurnal Agrijati, 28(1), 79-99.

Sutomo, H., Sukanata, I. K., \& Martani, K. R. (2015). Perilaku konsumen terhadap pembelian papaya california. Jurnal Agrijati, 28(1), 114-144.

WB WDI. (2015). Overiview konteks negara Indonesia. Diambil dari http://data.worldbank.org/sites/default/fil es/wdi-2012-ebook.pdf) [diunduh 19 Sept 2015].

Widiyanto, N. A., Adhi, A. K., \& Daryanto, H. K. (2016). Atribut-atribut yang mempengaruhi sikap dan preferensi konsumen dalam membeli buah apel di Kota Surabaya dan Kota Malang, Provinsi Jawa Timur. Jurnal IImu Keluarga dan Konsumen, 9(2), 136-146. doi: http://dx.doi.org/10.24156/jikk.2016.9.2.1 36. 